Marta Anastazja Wiśniewska

Faculty of Finance and Management

WSB University in Gdańsk, Poland

\title{
EUR/USD INTRADAY VOLATILITY VS TRADING RESULTS AND MARKET EFFICIENCY
}

\section{Abstract}

The paper tackles the problem of the efficiency of the foreign exchange market by examining selected intraday trading strategies. The research was conducted based on high-frequency data, i.e. one minute EUR/USD bid and ask rates. The paper demonstrates that a trading strategy based on high volatility and a mean-reversion pattern can provide outstanding results. This, in turn, is evidence against market efficiency, at least in the intraday horizon.

Keywords: volatility, efficiency, efficient market, intraday, high frequency, return, trading, foreign exchange market, EUR/USD.

\section{Introduction}

The efficient market hypothesis focuses on how information is incorporated into the prices of financial assets. The market for a financial asset is considered to be efficient if all available information on that asset is included in its price (Fama 1965, 1970). Since the release of new information is random, it should be impossible to discover a pattern that consistently provides abnormal returns. Nevertheless, the literature contains numerous studies of such patterns. Firm characteristics, such as the firm's size or PE ratio, have been identified as helpful in equity returns modelling (Fama \& French 1988). The same is true of time patterns such as the Monday effect (Gibbons \& Hess 1981).

Volatility and its patterns have often been perceived as helpful in explaining the behaviour of asset prices. Ever since their development, Engle's (1982) autoregressive conditional heteroscedasticity model (ARCH) and Bollerslev's (1986, 1987) generalised autoregressive conditional 
heteroscedasticity model (GARCH) have been widely used to help model asset returns and thus to establish potential patterns in asset prices. Furthermore, as Bollerslev et al. (1992, p. 32) have written, "the widespread existence of ARCH effects (...) have led researchers to search for its origin(s) (...) both on the micro and the macro level". While micro models are based on intraday data, macro models take account of fundamentals and news announcements.

Of all markets, the foreign exchange market has the highest capitalisation and trading volumes. Given its high liquidity, it is reasonable to expect 1) that any inefficiency resulting from patterns in prices will be quickly identified and promptly eliminated and 2) that the foreign exchange market will therefore be efficient. Under these market conditions it should be impossible to consistently achieve abnormal returns. While models that include fundamentals have helped to explain the behaviour of exchange rates in the long-term horizon, they have failed to do so in the short-term horizon. This is mostly due to the fact they are unable to tackle the high intraday volatility of exchange rates.

Day trading is often perceived as a lottery and its long-run profitability seen as a mystery (Statman 2002). Yet although there are relatively few day traders, they account for a relatively large part of the trading volume on each particular day (Barber \& Odean 1999; Barber et al. 2011; Kuo \& Lin 2013). Studies of the latter's profitability based on actual transaction data have suggested that only a comparatively small proportion of day traders - one in five when profits are measured after transaction costs - are profitable (Coval et al. 2005; Barber et al. 2011; Kuo \& Lin 2013). The fact that there are traders who are profitable in the long term means they must have identified trading strategies that provide abnormal returns, which in itself is against the random outcome of the lottery and therefore violates the efficient market hypothesis (Statman 2002).

There have been comparatively few studies of the intraday trading strategies that could be used to achieve significant profitability (Marshall et al. 2008a, 2008b; Schulmeister 2009; Yamamoto 2012). In one notable study, however, Holmberg, Lönnbark and Lundström (2013) have described a strategy known as Opening Range Breakout ${ }^{1}$, which is based on intraday momentum in asset prices and has enjoyed particular success in times of volatility clustering.

${ }^{1}$ The assumption of the Opening Range Breakout strategy is that if a price moves a certain percentage from the opening level the odds favour a continuation of that move until the market closes. 
Is it the case, though, that volatility clustering is a necessary condition for a profitable intraday strategy? Would high volatility combined with mean reversion not be a sufficient condition? More than this, would a strategy that explores high volatility and mean reversion not be consistently successful in intraday trading?

This study aimed to address these questions by providing an empirical investigation of the results of a trading strategy that is built upon high volatility and mean reversion. The strategy involves the simultaneous opening of short and long positions and waiting until a pre-determined take-profit level is reached. The underlying asset for trade used in the study is EUR/USD. This choice was based on (a) the mean reversion property of high frequency exchange rates and (b) extremely high liquidity and turnover of EUR/USD, which leads to high volatility. The study is innovative in its assertion that in the case of high frequency data it might not be necessary to build elaborated price or return based models to develop a successful trading strategy. Quite the contrary: it is assumed that in conditions of high volatility and mean reversion a much simpler strategy could prove successful.

The paper continues by presenting the dataset and methodology and giving a brief account of the trading strategy. It then proceeds to discuss the intraday EUR/USD volatility. Next the outcome of the trading strategy is investigated. The paper closes by setting out the conclusions of the empirical study.

\section{Methodology}

The study is based on one-minute EUR/USD exchange rates obtained from the Bank of America. Both ask and bid rates are represented by the last rate quoted - and used in the transaction - in that particular minute. Observations of 1,440 ask rates and 1,440 bid rates were collected for each day. The study covered a period of one year, which included 252 trading days ${ }^{2}$.

The study investigates two trading strategies: (1) a short-sell strategy whereby EUR/USD is sold (at bid rate $B$ at time $t=1$ ) ) $^{3}$ and then repurchased (at ask rate $a_{t}$ and at time $t=n$; where $n=2, \ldots, 1,440$ ) and (2) a strategy of "going long" whereby EUR/USD is first purchased (at ask rate $A$ and at time $t=1$ ) and later sold (at bid rate $b_{t}$ at some future time $t=n$; where

\footnotetext{
${ }^{2}$ Due to data availability, the study was undertaken for the EUR/USD exchange rate in 2005.

${ }^{3}$ The study defines $t=1$ in two ways: (a) as the first minute of each day and (b) (to check the consistency of the results) as the $360^{\text {th }}$ minute of the day (6.00 a.m. before the European exchanges open).
} 
$n=2, \ldots, 1,440)$. In this way there were 1,439 possible observations each day that could have indicated a profit (return) for each of the strategies:

$$
R_{S S}(t)=B-a_{t}
$$

and

$$
R_{S S}(t)=b_{t}-A,
$$

where $R_{S S}(t)$ is the return from (1) the strategy achieved ${ }^{4}$ at time $t=n$ (where $n=2, \ldots, 1,440)$, whereas $R_{B S}(t)$ is the return from (2) the strategy achieved at time $t=n$ (where $n=2, \ldots, 1,440$ ).

The level of volatility was measured by the standard deviation of intraday returns, which was preferred to implied volatility based on the finding in the literature that the former offers superior predictability (Taylor \& Xu 1997; Andersen \& Bollerslev 1998; Martens 2001; Neely 2002; Pong et al. 2004). A study of the level of volatility follows.

\section{Intraday Volatility}

Table 1 presents the summary statistics for both $R_{S S}$ and $R_{B S}$. For trades starting in the $1^{\text {st }}$ minute of the day, the average return achieved during one day while following strategy (1) was positive at 0.0008077 , while following strategy (2) it was negative at -0.0004691 . For trades starting in the $360^{\text {th }}$ minute the average returns achieved during one day were 0.0001078 for strategy (1) and -0.0007962 for strategy (2). When compared with the initial investment (the average exchange rate for the period was approximately $1.244)^{5}$, the following rates of return were produced $6.0 .064927 \%$ and $-0.037709 \%$ (for a position opened in the $1^{\text {st }}$ minute) and $0.00865 \%$, $-0.06400 \%$ (for positions opened in the $360^{\text {th }}$ minute). Since there were 252 trading days in the year, the annualised rates of return ${ }^{7}$ were: $17.77 \%$, $-9.067 \%, 2.2077 \%$ and $-14.9 \%$. Taking into consideration the leverage of $1: 25$, which is common in currency trading, these results can be boosted accordingly.

Table 1 also provides information on currency investment risk, which is measured by the standard deviation of intraday returns. For trades starting in the $1^{\text {st }}$ minute of the day the average risk was 3.37 times the

${ }^{4}$ The position is closed out at time $t$.

5 The average bid rate was 1.243826, and the average ask rate was 1.244157 .

${ }^{6}$ The rate of return is calculated as the ratio of profit (return) to the initial investment.

${ }^{7}$ Assuming compounding 252 times a year. 
Table 1. Intraday Volatility

\begin{tabular}{l|c|c|c|c}
\hline \multirow{2}{*}{} & \multicolumn{3}{|c|}{$R_{S S}$} & \multicolumn{2}{c}{$R_{B S}$} \\
\cline { 2 - 5 } & Average & $\begin{array}{c}\text { Standard } \\
\text { deviation }\end{array}$ & Average & $\begin{array}{c}\text { Standard } \\
\text { deviation }\end{array}$ \\
\hline Panel A: $t=1$ representing the $1^{\text {st }}$ minute of the day \\
\hline Median & 0.0008077 & 0.002725 & -0.0004691 & 0.002723 \\
\hline Standard deviation & -0.000229 & 0.00234 & -0.0004908 & 0.002345 \\
\hline Minimum & 0.0172079 & 0.001478 & 0.00374921 & 0.001478 \\
\hline Maximum & -0.01301 & 0.000704 & -0.0122131 & 0.000705 \\
\hline $1^{\text {st }}$ quintile & 0.26532 & 0.008097 & 0.0124127 & 0.008051 \\
\hline Percentile 0.1 & -0.002308 & 0.00159 & -0.002865 & 0.001596 \\
\hline Percentile 0.05 & -0.005139 & 0.001269 & -0.0050323 & 0.001268 \\
\hline Percentile 0.01 & -0.00636 & 0.001054 & -0.0065909 & 0.001068 \\
\hline \multicolumn{4}{|c|}{ Panel B: $t=1$ representing the 360 } & minute of the day \\
\hline Average & 0.0001078 & 0.003688 & -0.0007962 & 0.003682 \\
\hline Median & 0.0000383 & 0.003419 & -0.0007844 & 0.003398 \\
\hline Standard deviation & 0.0032532 & 0.001799 & 0.00326255 & 0.001795 \\
\hline Minimum & -0.010788 & 0.000955 & -0.0102338 & 0.000929 \\
\hline Maximum & 0.0097315 & 0.00962 & 0.009976 & 0.009506 \\
\hline $1^{\text {st } \text { quintile }}$ & -0.00183 & 0.002238 & -0.003055 & 0.002226 \\
\hline Percentile 0.1 & -0.003773 & 0.001598 & -0.0048391 & 0.001592 \\
\hline Percentile 0.05 & -0.00575 & 0.001378 & -0.0058548 & 0.001406 \\
\hline Percentile 0.01 & -0.008836 & 0.001038 & -0.0073065 & 0.001023 \\
\hline Source: auther & 0.000799 & -0.0100534 & 0.000804 \\
\hline
\end{tabular}

Source: author's own calculations.

average return for strategy (1) and 5.8047 times the average return for strategy (2). Meanwhile, for trades starting in the $360^{\text {th }}$ minute the average risk was 34.211 times the average return for strategy (1) and 4.62446 times the average return for strategy (2). These numbers imply that the risk (the volatility of returns) when compared to (average) returns can be relatively high. While volatility is undesirable on some markets, there are others on which increases in volatility increase the value of an asset (for example on an option market). The next section examines the returns from a trading strategy that utilises high volatility in its algorithm in order to achieve success, thus it gives an example of the implications of implementing a high volatility trading strategy. It then outlines the impact of high volatility on trading and profitability and hence on market efficiency. 


\section{Intraday Trading}

Table 2 presents the summary statistics for minimum and maximum returns per trading day. Though the average maximum return was positive for both strategies, it was higher for trades begun in the $360^{\text {th }}$ minute of the day than for those begun in the $1^{\text {st }}$ minute. Regardless of whether the position was opened in the $1^{\text {st }}$ or $360^{\text {th }}$ minute, the 0.05 percentile of maximum values was positive for both strategies. This led to the conclusion that there was a $95 \%$ probability that trades begun in the $1^{\text {st }}$ and $360^{\text {th }}$ minutes would provide positive returns within twenty-four hours. If both short and long positions were opened simultaneously, which meant executing strategies (1) and (2) together, the probability of a positive return from the joint position was $99 \%$ (see Table 3 ).

Table 2. Minimum and Maximum Intraday Returns

\begin{tabular}{|c|c|c|c|c|}
\hline & \multicolumn{2}{|c|}{$R_{S S}$} & \multicolumn{2}{|c|}{$R_{B S}$} \\
\hline & Minimum & Maximum & Minimum & Maximum \\
\hline \multicolumn{5}{|c|}{ Panel A: $t=1$ representing the $1^{\text {st }}$ minute of the day } \\
\hline Average & -0.00554 & 0.0050164 & -0.00571 & 0.0048416 \\
\hline Median & -0.0045 & 0.0039 & -0.0047 & 0.0039 \\
\hline Standard deviation & 0.004264 & 0.004221518 & 0.004219 & 0.004281447 \\
\hline Minimum & -0.0208 & -0.0005 & -0.0221 & -0.0005 \\
\hline Maximum & -0.0002 & 0.0214 & -0.0003 & 0.0203 \\
\hline $1^{\text {st }}$ quintile & -0.0073 & 0.0018 & -0.00788 & 0.0016 \\
\hline Percentile 0.1 & -0.01124 & 0.0005 & -0.0116 & 0.0005 \\
\hline Percentile 0.05 & -0.01466 & 0.000145 & -0.01492 & $4.5 \mathrm{E}-05$ \\
\hline Percentile 0.01 & -0.01945 & -0.0003 & -0.01775 & -0.0004 \\
\hline \multicolumn{5}{|c|}{ Panel B: $t=1$ representing the $360^{\text {th }}$ minute of the day } \\
\hline Average & -0.00644 & 0.006647826 & -0.00735 & 0.005783004 \\
\hline Median & -0.0053 & 0.0059 & -0.0067 & 0.0046 \\
\hline Standard deviation & 0.004546 & 0.004246909 & 0.004185 & 0.004535485 \\
\hline Minimum & -0.0222 & -0.0045 & -0.0242 & -0.0002 \\
\hline Maximum & 0.003036 & 0.0237 & -0.0005 & 0.0217 \\
\hline $1^{\text {st }}$ quintile & -0.0089 & 0.0036 & -0.0095 & 0.0024 \\
\hline Percentile 0.1 & -0.01324 & 0.00192 & -0.01268 & 0.00082 \\
\hline Percentile 0.05 & -0.01524 & 0.00086 & -0.01514 & 0.0005 \\
\hline Percentile 0.01 & -0.01968 & -0.000096 & -0.01967 & -0.000048 \\
\hline
\end{tabular}

Source: author's own calculations. 
Table 3. Intraday Maximum Return from Combining Strategies (1) and (2)

\begin{tabular}{l|c|c}
\hline \multirow{2}{*}{} & \multicolumn{2}{|c}{$R_{S S}+R_{B S}$} \\
\cline { 2 - 3 } & $1^{\text {st }}$ minute & $360^{\text {th }}$ minute \\
\hline Average & 0.009858 & 0.012431 \\
\hline Median & 0.00915 & 0.0121 \\
\hline Standard deviation & 0.003948 & 0.004924 \\
\hline Minimum & 0.0029 & -0.0007 \\
\hline Maximum & 0.0235 & 0.0282 \\
\hline $1^{\text {st }}$ quintile & 0.0067 & 0.0085 \\
\hline Percentile 0.1 & 0.0057 & 0.0065 \\
\hline Percentile 0.05 & 0.004845 & 0.006 \\
\hline Percentile 0.01 & 0.003698 & 0.00466 \\
\hline
\end{tabular}

Source: author's own calculations.

Table 2 also shows that for positions begun in the $360^{\text {th }}$ minute there was a $95 \%$ probability that strategy (1) would bring a return of at least 0.00086 and strategy (2) one of at least 0.0005 . Table 4 displays the results of trading strategies begun in the $360^{\text {th }}$ minute. A take-profit level of 0.00086 is used to close a position in strategy (1) and one of 0.0005 is used to close a position in strategy (2). On days when the take-profit levels were not reached, which was the case for $5 \%$ of the sample, the following scenarios - which use varying proxies for the return for the day in question - were considered: (a) the return was defined as the average return on that day; (b) the return was calculated as the difference between the average return and the standard deviation of returns on that day; (c) the return was calculated as the sum of the average return and the standard deviation of returns on that day; (d) zero return; (e) the return was defined as the minimum return on that day; and (f) the return was defined as the maximum return on that day.

The average return from strategy (1) under scenario (a) was 0.000531 , while from strategy (2) under the same scenario it was 0.000221 . This meant daily rates of return of $0.042685 \%$ and $0.0177653 \%$ respectively and annual rates of return of $11.3539 \%$ and $4.5782 \%$ (compounded 252 times a year).

Under scenario (a) the average return produced by combining strategies (1) and (2), which entailed opening short and long positions simultaneously, was $0.000376(0.03022 \%)$ giving an annual rate of return of $7.9131 \%$. When allowing for leverage of 1:25 this can be boosted to $197.8275 \%$. Taking into consideration that there is a $95 \%$ probability of achieving it, this is an impressive figure indeed and one that could be taken to demonstrate the 
superiority of the strategy and the inefficiency - at least so far as intraday trading is concerned - of the foreign exchange market.

Table 4. Average Daily Return as a Result of Implementing the Trading Strategies

\begin{tabular}{l|c|c|c}
\hline \multicolumn{1}{c|}{ Scenario } & $R_{S S}$ & $R_{B S}$ & $R_{S S}+R_{B S}{ }^{*}$ \\
\hline \multicolumn{3}{c}{$t=1$ representing the $360^{\text {th }}$ minute of the day } \\
\hline (a) Average & 0.000531 & 0.000221 & 0.000376 \\
\hline (b) Average - Std. dev & 0.000355 & 0.000077 & 0.000216 \\
\hline (c) Average + Std. dev & 0.000708 & 0.000365 & 0.000536 \\
\hline (d) Zero Return & 0.000816 & 0.000476 & 0.000646 \\
\hline (e) Minimum & 0.000221 & -0.000042 & 0.000090 \\
\hline (f) Maximum & 0.000814 & 0.000481 & 0.000648 \\
\hline
\end{tabular}

Executing both strategies simultaneously doubles the investment. Therefore, for the purposes of comparison, the return was divided by 2 .

The scenarios used for the days when the take-profit level is not reached vary in terms what is considered a return from the position: (a) obtaining the average return on that day, (b) obtaining a return equal to the difference between the average return and the standard deviation, (c) obtaining a return equal to the sum of the average return and the standard deviation, (d) obtaining zero return, (e) obtaining the minimum return on that day, (f) obtaining the maximum return on that day.

Source: author's own calculations.

Two factors limited the analysis: (1) the one-day trading horizon and (2) the lack of analysis of the size of margin account necessary to implement the strategy. Where the take-profit target was not satisfied, the study did not allow for a position to be held for more than twenty-four hours. Given that the mean-reverting properties of EUR/USD had been identified in earlier research, it may have been the case that allowing a position to remain open for longer would have improved the results further. Although results can be improved by the leverage often applied in currency trading, it remains necessary to monitor the margin account to ensure that positions are not automatically closed out at a loss when the balance of the margin account is insufficient. Unfortunately, maintaining a margin account can be costly. It would be interesting to see how margin requirements change, and what consequences these changes might have, when holding an open position resulting from the trading strategies outlined in the study. 


\section{Conclusions}

The study has investigated the efficiency of the foreign exchange market by examining the performance of a chosen intraday trading strategy. The strategy selected, which was built upon high volatility and the mean-reversion pattern in high frequency EUR/USD data, involved opening a short and long position at the same time and setting target take-profit levels to close out the positions. The study has proved that implementing this strategy with a leverage of 1:25 can provide surprisingly high returns. The results are of particular interest because they were achieved with $95 \%$ probability.

Good in-sample performance of the trading strategy provides evidence that, where intraday trading is concerned, the foreign exchange market is not efficient, and certain patterns can be identified and explored. The study has several limitations, some of which are outlined in the section above. Others could be overcome by providing satisfactory answers to the following questions: What is the impact of the time at which the position is initially opened (the study allowed the position to be opened in either the $1^{\text {st }}$ or $360^{\text {th }}$ minute)? How robust are the results in relation to the time period used in the study? How would the results be affected if the study period was extended? Adequate responses to these questions may be sought in further studies.

\section{Bibliography}

Andersen, T. G. and Bollerslev, T. (1998) "Answering the Skeptics: Yes, Standard Volatility Models do Provide Accurate Forecasts". International Economics Review 39: 885-905.

Barber, B. M., Lee, Y., Liu, Y. and Odean, T. (2011) "The Cross-section of Speculator Skill: Evidence from Day Trading”. Working Paper. University of California at Davis and Peking University and University of California, Berkeley.

Barber, B. M. and Odean, T. (1999) "The Courage of Misguided Convictions". Financial Analysts Journal 55: 41-55.

Bollerslev, T. (1986) "Generalized Autoregressive Conditional Heteroskedasticity". Journal of Econometrics 31: 307-27.

Bollerslev, T. (1987) "A Conditional Heteroskedastic Time Series Model for Speculative Prices and Rates of Returns". Review of Economics and Statistics 69: 542-47.

Bollerslev, T., Chou, R. Y. and Kroner, K. F. (1992) "ARCH Modeling in Finance: A Selective Review of the Theory and Empirical Evidence". Journal of Econometrics 52: 5-59.

Coval, J. D., Hirshleifer, D. A. and Shumway, T. (2005) "Can Individual Investors Beat the Market?". Working Paper No. 04-025. Harvard University, School of Finance.

Engle, R. F. (1982) "Autoregressive Conditional Heteroskedasticity with Estimates of the Variance of UK inflation". Econometrica 50: 987-1008.

Fama, E. (1965) “The Behavior of Stock Market Prices”. Journal of Business 38: 34-105. 
Fama, E. (1970) "Efficient Capital Markets: A Review of Theory and Empirical Work". Journal of Finance 25(2): 383-417.

Fama, E. and French, K. R. (1988) "Permanent and Temporary Components of Stock Prices". Journal of Political Economy 96 (April): 246-73.

Gibbons, M. R. and Hess, P. J. (1981) "Day of the Week Effects and Asset Returns". Journal of Finance 54: 579-96.

Holmberg, U., Lönnbark, C. and Lundström, C. (2013) "Assessing the Profitability of Intraday Opening Range Breakout Strategies". Finance Research Letters 10: 27-33.

Kuo, W-Y. and Lin, T-C. (2013) "Overconfident Individual Day Traders: Evidence from the Taiwan Futures Market”. Journal of Banking and Finance 37(9): 3548-61.

Marshall, B. R., Cahan, R. H. and Cahan, J. M. (2008a) "Can Commodity Futures be Profitably Traded with Quantitative Market Timing Strategies?”. Journal of Banking and Finance 32: 1810-19.

Marshall, B. R., Cahan, R. H. and Cahan, J. M. (2008b) "Does Intraday Technical Analysis in the US Equity Market Have Value?". Journal of Empirical Finance 15: 199-210.

Martens, C. (2001) "Forecasting Daily Exchange Rate Volatility Using Intraday Returns". Journal of International Money and Finance 20: 1-23.

Neely, C. J. (2002) "Forecasting Foreign Exchange Volatility: Is Implied Volatility the Best that We Can Do?". Working Paper No. 2002-017. Federal Reserve Bank of St Louis.

Pong, S., Shackleton, M. B., Taylor, S. J. and Xu, X. (2004) "Forecasting Currency Volatility: A Comparison of Implied Volatilities and AR(FI)MA Models". Journal of Banking and Finance 28(10): 2541-63.

Schulmeister, S. (2009) "Profitability of Technical Stock Trading: Has It Moved from Daily to Intraday Data?". Review of Financial Economics 18: 190-201.

Statman, M. (2002) "Lottery Players / Stock Traders". Financial Analysts Journal 58: 14-21. Taylor, S. J. and Xu, X. (1997) “The Incremental Volatility Information in One Million Foreign Exchange Quotations”. Journal of Empirical Finance 4: 317-40.

Yamamoto, R. (2012) "Intraday Technical Analysis of Individual Stocks on the Tokyo Stock Exchange". Journal of Banking and Finance 36: 3033-47.

\section{Abstract}

\section{Zmienność kursu EUR/USD w ciągu doby a strategia inwestycyjna i efektywność rynku}

Praca porusza problem efektywności rynku walutowego poprzez ukazanie wyników inwestycyjnych dobowej strategii inwestycji. Badanie zostało przeprowadzone na podstawie danych wysokiej częstotliwości, tj. jednominutowych danych kursu kupna i sprzedaży EUR/USD. W pracy wykazano, że strategia oparta na założeniu wysokiej zmienności i tendencji powrotu do średniej może zapewnić doskonałe wynki inwestycyjne. Jednocześnie stwierdzono, że z uwagi na powyższe wyniki rynek walutowy nie jest efektywny w krótkim, dobowym kontekście.

Słowa kluczowe: zmienność, efektywność, rynek efektywny, stopy zwrotu, wysoka częstotliwość, rynek walutowy, EUR/USD. 